\title{
Invariant Natural Killer T (iNKT) cells response in human melioidosis
}

\author{
Ludthawun Kamuthachad, ${ }^{1,2}$ Pornrith Pisuttimarn, ${ }^{3}$ Thitinan Kasetthat, ${ }^{1,2}$ Ploenchan Chetchotisakd, ${ }^{4}$ Siriluck Anunnatsiri, ${ }^{4}$ \\ Rasana W. Sermswan, ${ }^{2,5}$ Hiroshi Watarai, ${ }^{6}$ Ponpan Matangkasombut, ${ }^{7,8}$ Surasakdi Wongratanacheewin ${ }^{1,2}$
}

\begin{abstract}
Background: Melioidosis is an infectious disease caused by Burkholderia pseudomallei. In infected mice, IFN- $\gamma$ can provide protection against $B$. pseudomallei infection. Invariant Natural Killer T (iNKT) cells are a subpopulation of T lymphocytes, activated by recognition of glycolipid ligands such as a-Galactosylceramide presented by CD1d, produce and secrete several cytokines, including IFN- $\gamma$ and IL-4. The response of iNKT cells in human melioidosis was then investigated.
\end{abstract}

Objectives: To determine the iNKT cells response in human melioidosis.

Methods: The number of human iNKT cells and its activation states were investigated in sepsis melioidosis patients compared with healthy controls using flow cytometry. The iNKT cells activation was confirmed in vitro using heatkilled B. pseudomallei with normal peripheral blood mononuclear cells. The components induced iNKT cell were also determined using different concentration of B. pseudomallei lipopolysaccharide (LPS), heat-killed B. pseudomallei treated with or without DNase, RNase, or proteinase.

Results: The number of human iNKT cells was significantly lower while the percentage of activated iNKT cells was higher in sepsis melioidosis when compared to control. In addition, B. pseudomallei can stimulate human iNKT cells in vitro. Heat-killed B. pseudomallei could activate iNKT cells but not relate to nucleic acid, proteins, or LPS.

Conclusions: We found for the first time that the iNKT cells were activated during B. pseudomallei infection in human. However, the roles and the mechanism of iNKT cells during early state of infection needed to be further investigated.

Key words: Burkholderia pseudomallei, melioidosis, iNKT cells, activation, human infection

\footnotetext{
Affiliations:

${ }^{1}$ Department of Microbiology, Faculty of Medicine, Khon Kaen University, Thailand

${ }^{2}$ Melioidosis Research Center, Khon Kaen University, Thailand

${ }^{3}$ Khon Kaen Hospital, Khon Kaen, Thailand

${ }^{4}$ Department of Medicine, Srinagarind Hospital, Faculty of Medicine, Khon Kaen University, Thailand

Department of Biochemistry, Faculty of Medicine, Khon Kaen University, Khon Kaen, Thailand

${ }^{6}$ Department of Immunology and Stem Cell Biology, Faculty of Medicine, Institute of Medical, Pharmaceutical and Health Sciences, Kanazawa University, Kanazawa, Ishikawa, Japan

Department of Microbiology, Faculty of Science, Mahidol University, Bangkok, Thailand

${ }^{8}$ Systems Biology of Diseases Research Unit, Faculty of Science, Mahidol University, Bangkok, Thailand
}

\section{Corresponding author:}

Surasakdi Wongratanacheewin

Department of Microbiology, Faculty of Medicine,

Khon Kaen University, Khon Kaen, 40002, Thailand

E-mail: sura_wng@kku.ac.th

\section{Introduction}

Melioidosis is an infectious disease caused by a Gram-negative bacterium, Burkholderia pseudomallei. Disease manifestations range from acute fulminant sepsis to chronic infection. ${ }^{1}$ Most melioidosis patients present with sepsis with or without pneumonia. ${ }^{2}$ In northeast Thailand, melioidosis shows a $40 \%$ mortality rate in septicemia, even after treatment. ${ }^{3}$ Melioidosis patients have elevated several cytokines such as IFN- $\gamma$, IL-8, IL-12, and IL-15 during sepsis melioidosis. ${ }^{4}$ IFN- $\gamma$ that is produced from Natural killer (NK) cells and $\mathrm{T}$ cells have been implicated in survival from acute melioidosis. ${ }^{5}$ When the PBMCs of those who recovered from melioidosis disease were stimulated with B. pseudomallei antigens, they generated an antigen-specific IFN- $\gamma$ immune response to B. pseudomallei. This indicated the role of IFN- $\gamma$ in protection against infection. ${ }^{6}$ 
Invariant natural killer T (iNKT) cell is a distinct population of $\mathrm{T}$ lymphocytes that express natural killer (NK) receptor (NK 1.1 in the mouse and NKR-P1A in humans) and a semi-invariant $\mathrm{T}$ cell receptor (TCR), Va14Ja18 paired with $\mathrm{V} \beta 8.2, \mathrm{~V} \beta 7$, or $\mathrm{V} \beta 2$ in mice and $\mathrm{V} \alpha 24 \mathrm{~J} \alpha 18 / \mathrm{V} \beta 11$ in human. ${ }^{7,8}$ The iNKT cells recognize lipid or glycolipid antigens presented by MHC class I-like antigen-presenting molecule, CD1d on antigen-presenting cells (APCs). During infection, iNKT cells produce cytokines such as IFN- $\gamma$ and IL-4 that recruit and stimulate other cell types, including macrophages, neutrophils, dendritic cells (DCs), NK cells, T, and B cells. ${ }^{9}$ iNKT cells can be activated by direct recognition of microbial lipid antigens or modified endogenous lipid presented on CD1d via a $\mathrm{T}$ cell receptor (TCR)-dependent manner leading to rapid production of a large number of cytokines. ${ }^{10,11}$ Further, iNKT cells can also be activated indirectly through cytokine-mediated activation or combination of both. ${ }^{12,13}$ These properties enable iNKT cells to expand the protective response of the innate immune cells such as macrophages, and neutrophils that important in controlling B. pseudomallei infection. ${ }^{14,15} \mathrm{Al}$ though there was reported a slightly lower number of NKTlike cells in dead melioidosis cases ${ }^{5}$ however little is known about the role of iNKT cells during this disease. This study therefore intends to explore their role during B. pseudomallei infection.

In this study, we assessed the response of the iNKT cell in melioidosis by evaluating iNKT cells number and activation level in melioidosis patients as well as the disease outcome. This study demonstrated that B. pseudomallei could induce human iNKT cells activation both in vivo and in vitro. Moreover, the LPS, nucleic acids and proteins fractions from heat-killed B. pseudomallei did not involve in the activation of iNKT cells.

\section{Methods \\ Sample collections}

Human blood samples $(10 \mathrm{ml})$ were collected from 13 patients within 7 days of admission to Srinagarind or Khon Kaen Provincial hospitals with acute melioidosis and culture-proven for B. pseudomallei. Normal blood samples ( $\mathrm{n}=$ 10 ; male $=4$, female $=6$, age ranges $25-32$ years-old) were also obtained from healthy adults as a control. The study was approved by the human ethics committee of Khon Kaen
University (in-vivo HE591293 and in-vitro HE621362) and the human ethics committee of Khon Kaen hospital (KE61048). Written inform consent was obtained from all participating patients. The inclusion and exclusion criteria for recruitment of patients with sepsis melioidosis ${ }^{16}$ are shown in table 1.

\section{Isolation of Human Peripheral Blood Mononuclear Cells (PBMCs)}

Peripheral Blood Mononuclear Cells (PBMCs) were isolated from whole blood samples by density gradient using the Ficoll-hypaque (GE Healthcare, Uppsala, Sweden). The cells were washed twice with phosphate buffer saline (PBS), pH 7.4 and re-suspended in an $\mathrm{R} 10^{+}$medium comprising RPMI1640 supplemented with $10 \%$ fetal bovine serum (FBS), $100 \mathrm{U} \mathrm{ml-1}$ penicillin-streptomycin, $10 \mathrm{mM}$ HEPES buffer solution and $5.5 \mu \mathrm{M}$ 2-Mercaptoethanol (2-ME). ${ }^{17}$ Ten microliters of the cell were used to measure their viability using a trypan blue exclusion assay (Gibco, Thermo Fisher Scientific, Waltham, MA) and the rest were kept at $4^{\circ} \mathrm{C}$. The final cell number was $0.5-1.0 \times 10^{7}$ cells $/ \mathrm{ml}$ with total of $1 \mathrm{ml}$ for in vitro experiment and flow cytometry.

\section{Bacteria}

A single colony of $B$. pseudomallei strain $1026 \mathrm{~b}$ grown on selective Ashdown's agar was inoculated into $3 \mathrm{ml}$ Luria-Bertani (LB) broth (Titan Biotech LTD., Rajasthan, India) and cultured overnight at $37^{\circ} \mathrm{C}$ with occasional shaking at 200 $\mathrm{rpm}$. Subsequently, $2 \%$ of the culture was inoculated into 50 $\mathrm{ml} \mathrm{LB}$ broth and cultured for 3 hours with shaking at 200 $\mathrm{rpm}$ in a $37^{\circ} \mathrm{C}$ shaker incubator (J.P. SELECTA, Barcelona, Spain) to reach the log phase. The bacterial cell pellets were centrifuged at 10,000 g for 10 minutes and washed with PBS, $\mathrm{pH} 7.4$ before re-suspended in $1 \mathrm{ml} \mathrm{PBS}$ and kept at $4^{\circ} \mathrm{C}$ until use. To prepare heat-killed B. pseudomallei, $1 \times 10^{8} \mathrm{CFU} /$ $\mathrm{ml}$ of the bacterium were heated for 1 hour at $80^{\circ} \mathrm{C}$ and then checked for their viability. ${ }^{18}$

\section{Heat-Killed bacteria treated with enzymes}

Five hundred microliters of $1 \times 10^{7} \mathrm{CFU} / \mathrm{ml}$ of heatkilled bacterium were treated with 1 unit of DNase (Promega, Madison, WI) or $100 \mu \mathrm{g}$ of RNase (Thermo scientific, Carlsbad, CA) or $100 \mu \mathrm{g}$ of proteinase (Promega, Madison, WI) or $\mathrm{PBS}$ as a control for overnight at $37^{\circ} \mathrm{C}$. After treatment,

Table 1. Inclusion and Exclusion criteria for blood sample collection

\begin{tabular}{|c|c|c|c|}
\hline Group of samples & $\mathbf{N}$ & Inclusion criteria & Exclusion criteria \\
\hline Healthy donors & 10 & Age more than 18 years-old & - \\
\hline Melioidosis donors & 13 & $\begin{array}{l}\text { 1. Age more than } 18 \text { years-old } \\
\text { 2. Culture-proven } B \text {. pseudomallei infection } \\
\text { 3. Sepsis caused by melioidosis was defined by the presence } \\
\text { of } \geq 2 \text { of the following characteristics } \\
3.1 \text { Temperature }>38^{\circ} \mathrm{C} \text { or }<36^{\circ} \mathrm{C} \\
3.2 \text { Pulse rate }>90 \text { beats } / \mathrm{min} \\
3.3 \text { Respiratory rate }>20 \text { breaths } / \text { min or partial pressure } \\
\text { of } \mathrm{CO}_{2} \text { arterial }<32 \mathrm{mmHg} \\
\text { 3.4 White blood cell }(\mathrm{WBC}) \text { count }>12,000 \times 10^{6} \text { cells } / 1 \\
\text { or band forms }>10 \%\end{array}$ & $\begin{array}{l}\text { 1. Patients active with cancer } \\
\text { 2. Patients with other infection } \\
\text { 3. Patients received these anti-inflammatory drugs indicated } \\
\text { as follows } \geq 2 \text { weeks before recruit to this study } \\
3.1 \text { Prednisolone }>20 \mathrm{mg} / \text { day } \\
3.2 \text { Hydrocortisone }>80 \mathrm{mg} / \text { day } \\
3.3 \text { Dexamethasone }>3 \mathrm{mg} / \text { day }\end{array}$ \\
\hline
\end{tabular}


the enzymes were heated inactivated at $95^{\circ} \mathrm{C}$ for 15 minutes. The heat-killed bacteria were checked for bacterial lysis and the enzymes digestions were completed.

\section{In vitro iNKT cell activation with heat-killed B. pseudomal-} lei

The MOI ratio used in this experiment was chosen from several ratios between heat-killed $B$. pseudomallei: PBMC, including $10\left(1 \times 10^{6} \mathrm{CFU}\right): 1,50\left(5 \times 10^{6} \mathrm{CFU}\right): 1$, and $100(1 \times$ $\left.10^{7} \mathrm{CFU}\right): 1$. (Supplement Figure 1). The MOI 10 was selected to use in the experiment because it was sufficient to stimulate iNKT cells. The $1 \times 10^{5}$ human PBMCs in $50 \mu \mathrm{l}$ of $\mathrm{R} 10^{+}$ medium was incubated with $50 \mu \mathrm{l}$ of $1 \times 10^{6} \mathrm{CFU}$ heat-killed B. pseudomallei or enzymes treated heat-killed B. pseudomallei $(\mathrm{MOI}=10)$ in $\mathrm{R} 10^{+}$media in a 96 -well plate, U-Bottom $(\mathrm{BD}$, Falcon, USA) at $37^{\circ} \mathrm{C}$ for 24 hours. PBMCs with $\mathrm{R} 10^{+}$alone served as an unstimulated control. After incubation, cells were collected and their viability were checked using a trypan blue staining method as recommended by the manufacturer (Gibco, Thermo Fisher Scientific, Waltham, MA). The activation state of iNKT cells were then assessed by CD69 expression in comparison to isotype-matched controls mAb (mouse IgG1) using flow cytometry. ${ }^{19}$

\section{In vitro PBMC activation with B. pseudomallei lipopolysac- charide (LPS)}

The $1 \times 10^{5}$ human PBMCs were cultured in $100 \mu \mathrm{l}$ of $\mathrm{R} 10^{+}$medium in the presence of $1,10,100$, and $1,000 \mathrm{ng} / \mathrm{ml}$ of B. pseudomallei LPS (kindly provided by Associate Prof. Narisara Chantratita, Mahidol University, Thailand) ${ }^{20}$ for 24 hours. Then, the activated iNKT cells in the PBMCs were assessed by flow cytometry.

\section{Flow cytometry analysis of human iNKT cells}

PBMCs $\left(1 \times 10^{5}-1 \times 10^{6}\right.$ cells $)$ were suspended $50 \mu \mathrm{l}$ of staining buffer (2\% (vol/vol) FBS, and $0.09 \%$ (wt/vol) sodium azide in PBS) and incubated with $2.5 \mu \mathrm{g}$ of Fc block (BD Biosciences, San Diego, CA) at room temperature for 10 minutes followed by staining with optimum concentration of antibodies recommended by the manufacturers; APC-labeled a-GalCer/human CD1d dimer (BD Biosciences, San Diego, CA), and followed by FITC-conjugated anti-human $\alpha \beta$ TCR (Thermo, Waltham, MA) mAb, peridinin chlorophyll protein-cyanine 5.5 (PerCP-Cy5.5)-conjugated anti-human CD19 mAb (Thermo, Waltham, MA), and brilliant violet (BV421)-conjugated anti-human CD69 mAb (BioLegend, San Diego, CA) for 15-30 minutes at $4^{\circ} \mathrm{C}$ in the dark. ${ }^{17}$ Unloaded CD1d dimer or isotype matched control antibodies were used for detecting non-specific binding and set up cut-off value of negative and positive staining cells. The cells were then washed and re-suspended with staining buffer. Finally, samples were acquired by flow cytometer (Beckton Dickinson/FACSCanto II) and data were analyzed by FlowJo software (Tree star).

\section{Statistical analysis}

Statistical analyses were performed by using SPSS version 20 and GraphPad Prism 5.0. Mann-Whitney U-test was used to compare unpaired data. The two-way analysis of variance (ANOVA) was used to analyze differences in multiple groups. A $p$-value of $<0.05$ was considered as statistically significant.

\section{Results}

\section{iNKT cells in melioidosis patients}

The responses of human iNKT cells to B. pseudomallei was investigated in melioidosis patients compared with healthy controls. Their demographic data for healthy controls (Table 2) and melioidosis patients were shown (Table 3). Most patients were males and diabetes were a major underlying disease. The percentage of circulating iNKT cells in total lymphocytes was significantly lower $(p=0.0019)$ in melioidosis patients (median $0.042 \%$; interquartile range 0.02 $0.07 \%$ ) than in the healthy controls (median $0.117 \%$; interquartile range $0.06-0.22 \%$ ) (Figure 1B). The same result was also found when iNKT cells were calculated within absolute $\mathrm{T}$ cells (median 0.091\%; interquartile range 0.05-0.19\% and median $0.265 \%$; interquartile range $0.19-0.43 \%$ for melioidosis patients and control respectively) $(p=0.0041)$ (Figure 1C).

Table 2. Demographic data of healthy controls

\begin{tabular}{lc}
\multicolumn{1}{|l}{ Demographic data } & Number of donors \\
\hline Ages (years, mean \pm SD) & $27 \pm 2$ \\
Gender & \\
Male & 4 \\
\hline Female & 6 \\
\hline
\end{tabular}

Table 3. Demographic data of melioidosis patients

\begin{tabular}{|c|c|c|}
\hline Demographic data & $\begin{array}{l}\text { Patients who } \\
\text { survived }\end{array}$ & $\begin{array}{c}\text { Patients } \\
\text { who died }\end{array}$ \\
\hline Number of patients, $\mathrm{n}$ & 10 & 3 \\
\hline Ages (years, mean \pm SD) & $57 \pm 8$ & $64 \pm 7$ \\
\hline \multicolumn{3}{|l|}{ Gender } \\
\hline Male & 7 & 3 \\
\hline Female & 3 & 0 \\
\hline \multicolumn{3}{|l|}{ Underlying disease } \\
\hline None & 2 & 0 \\
\hline Diabetes (type 2) & 7 & 2 \\
\hline Chronic obstructive pulmonary disease & 1 & 1 \\
\hline \multicolumn{3}{|l|}{ Type of specimen for bacterial culture } \\
\hline Blood & 7 & 3 \\
\hline Pus & 3 & 0 \\
\hline
\end{tabular}


(A)
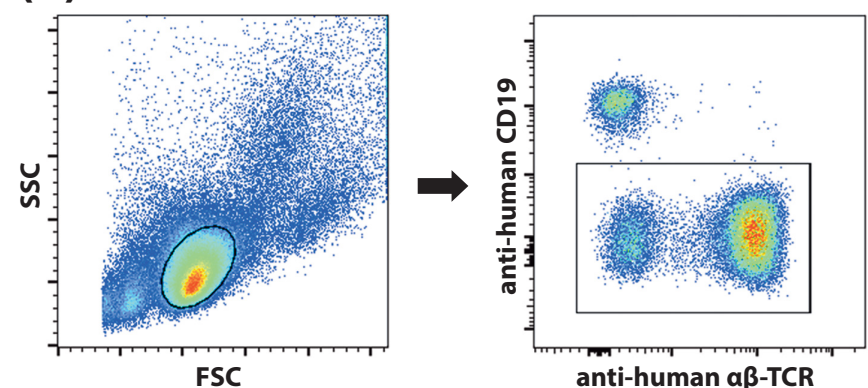

anti-human $\boldsymbol{\alpha} \beta$-TCR

(B)

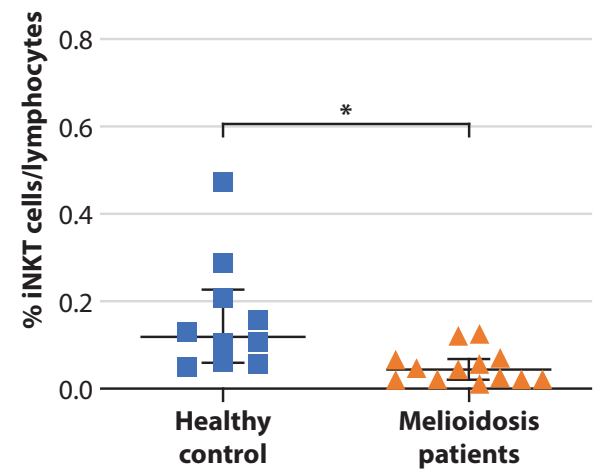

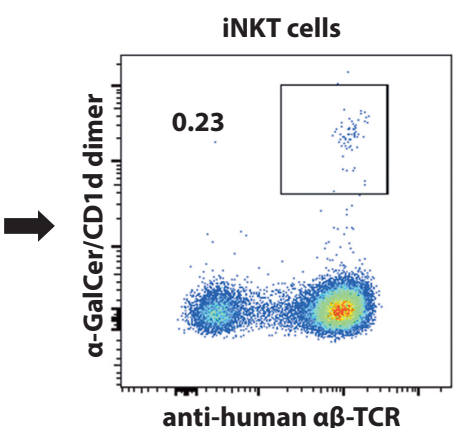

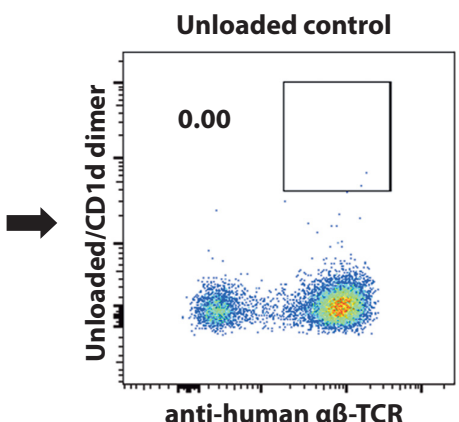

(C)

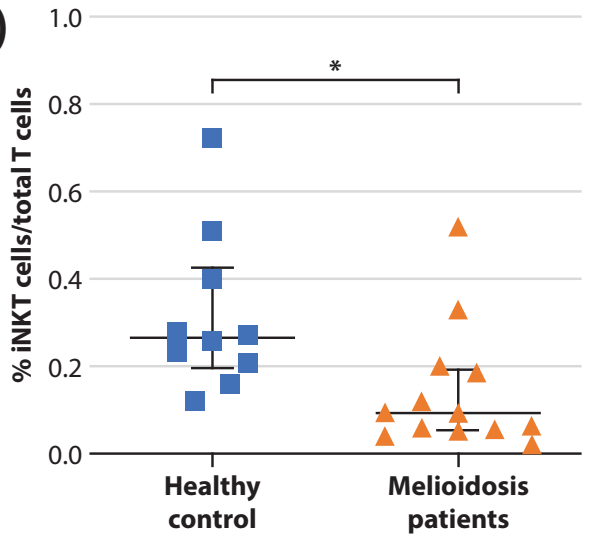

Figure 1. The frequency of circulating iNKT cells in melioidosis patients compared with healthy controls.

PBMCs were incubated with monoclonal antibodies specific to iNKT cells and analyzed by flow cytometer. (A) Flow cytometry gating strategies for human iNKT cells. From left to right, after selection for lymphocytes by FSC-SSC, B cells were excluded by anti-human CD19. Finally, iNKT cells were identified by using (mAbs) anti-human $\alpha \beta$ TCR and $\alpha$-GalCer/human CD1d dimer (in comparison with Unloaded/human CD1d dimer as control). (B) The percentage of circulating iNKT cells within total lymphocytes and $(\mathrm{C})$ within total $\mathrm{T}$ cells obtained from melioidosis patients $(\mathrm{N}=13$; orange triangles) compared to healthy controls $\left(\mathrm{N}=10\right.$; blue squares). Data represented as the median with interquartile range $\left({ }^{\star} P<0.05\right.$ compared between two groups of samples).

(A)

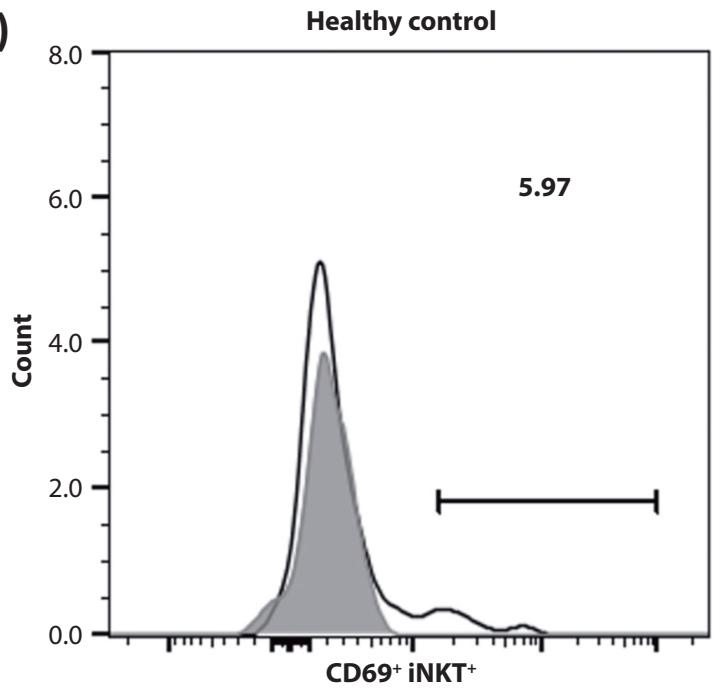

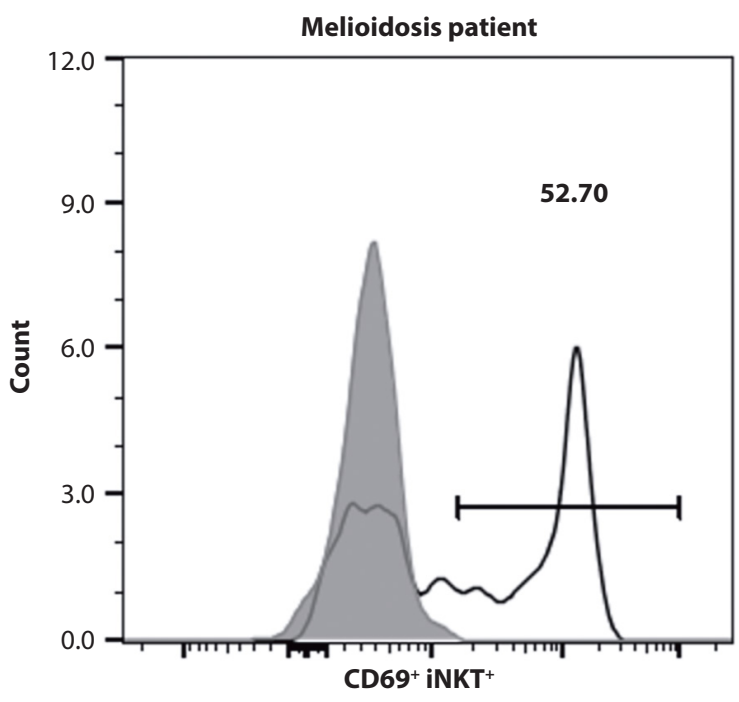

Isotype

Figure 2. The activation of iNKT cells in melioidosis

(A) Representative histograms showing the CD69 expression on iNKT cells (black line) as an activation marker compared with isotype control (gray shade) of a healthy control and a melioidosis patient. (B) Expression of CD69 in circulating iNKT cells obtained from melioidosis patients ( $\mathrm{n}=13$; orange triangles) was compared to healthy controls $(\mathrm{n}=10$; blue squares). Data represented as the median with interquartile range $\left({ }^{\star} P<0.05\right.$ compared between two groups of samples). 


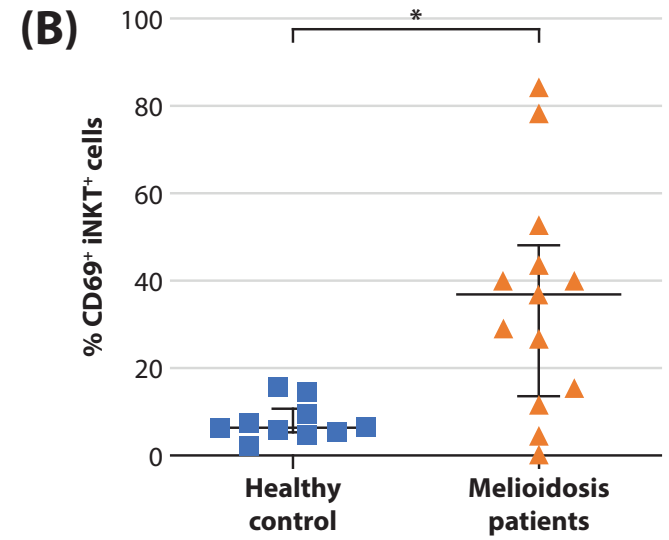

Figure 2. (Continued)

In contrast, the activated iNKT cells of melioidosis patients were significantly higher than in the controls (median $36.84 \%$; interquartile range $13.48-48.09 \%$ and median $6.25 \%$; interquartile range 5.16-10.58\%, respectively) $(p=0.0062)$ (Figure 2B).

\section{B. pseudomallei stimulated iNKT cells in vitro}

When human PBMCs were cultured with heat-killed $B$. pseudomallei in vitro, the number of iNKT cells was similar to unstimulated controls (median $0.161 \%$; interquartile range $0.10-0.28 \%$ and median $0.161 \%$; interquartile range 0.08 $0.27 \%$, respectively) (Figure 3A). Similar to what observed in patients, the number of activated iNKT cells in the human PBMCs stimulated with the heat-killed B. pseudomallei was also significantly higher than the unstimulated control (median 28.60\%; interquartile range $20.25-58.47 \%$ and median $8.63 \%$; interquartile range $3.78-13.00 \%$, respectively) ( $p=$ 0.0005) (Figure 3B).

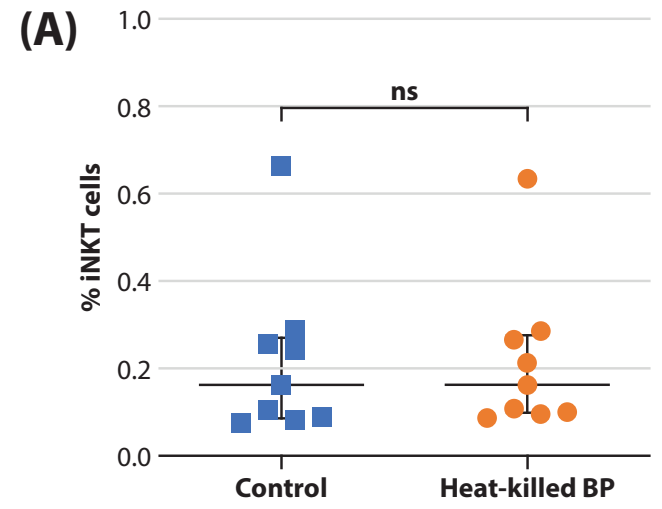

Stimulation of PBMCs with heat-killed B. pseudomallei showed significantly higher of $\% \mathrm{CD} 9^{+}$iNKT cells (mean \pm $\mathrm{SE}=58.60 \pm 18.12)$ when compared with the non-stimulated controls $(1.20 \pm 0.22)(p=0.0309)$ (Figure 3C). Furthermore, the activation was found to be dose-dependent (Supplement Figure 1). Additional treatment of heat-killed B. pseudomallei with DNase, RNase, or proteinase similarly showed higher iNKT cell activation $(57.33 \pm 20.22,57.17 \pm 19.60,57.33$ \pm 21.74 , respectively) when compared to the control conditions $(0.88 \pm 0.06,0.82 \pm 0.01$ and $0.80 \pm 0.40, p=0.0346$, 0.0350 and 0.0342 , respectively), however, no changes were found when compared to untreated heat-killed B. pseudomallei (Figure 3C). Taken together, heat-killed B. pseudomallei could activate iNKT cells in vitro and DNase, RNase and proteinase-treated heat-killed B. pseudomallei did not alter iNKT cells activation. This suggesting that nucleic acid and protein components are not responsible for iNKT cells activation. When $B$. pseudomallei LPS was used to activate the iNKT cells in human PBMC, it also did not response (Figure 3D).

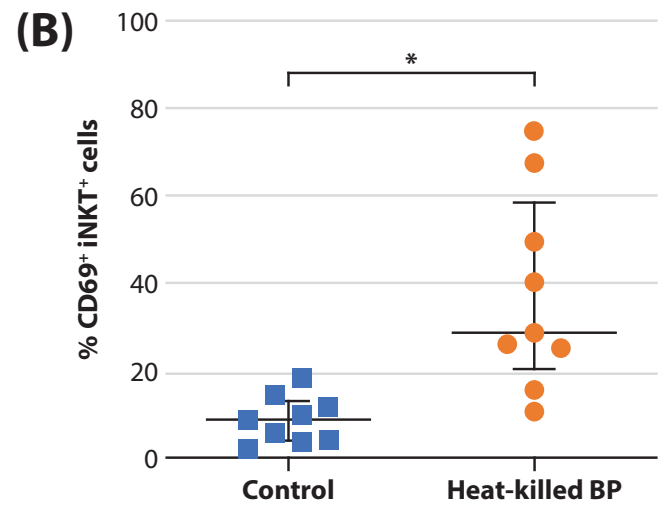

Figure 3. The percentage of iNKT cells and activated iNKT cells in human PBMCs when stimulated with heat-killed $B$. pseudomallei or LPS in vitro.

(A) The percentage of iNKT cells and (B) the number of $\mathrm{CD} 69^{+}$iNKT cells were activated with heat-killed $\mathrm{B}$. pseudomallei in vitro. The PBMCs obtained from healthy controls were treated with heat-killed B. pseudomallei (10:1 ratio; heat-killed B. pseudomallei: PBMCs) for 24 hours. (C) The iNKT cells activation from human PBMCs were cultured with heat-killed B. pseudomallei treated DNase, RNase, proteinase or PBS and heat-killed B. pseudomallei (HKBP) without treatment was used as positive control. (D) The percentage of iNKT cells was activated with different concentration of LPS from B. pseudomallei (LPS 1-1000 ng/ml) for 24 hours. The medium $\mathrm{R} 0^{+}$and whole heat-killed B. pseudomallei were used as negative and positive control, respectively. After incubated, PBMCs were harvested and stained with antibodies to measure \%CD69+ iNKT cells by flow cytometer as in Methods. Data represented as the mean $\pm \mathrm{SE}\left({ }^{\star} P<0.05\right.$ compared between control and activation sample). 


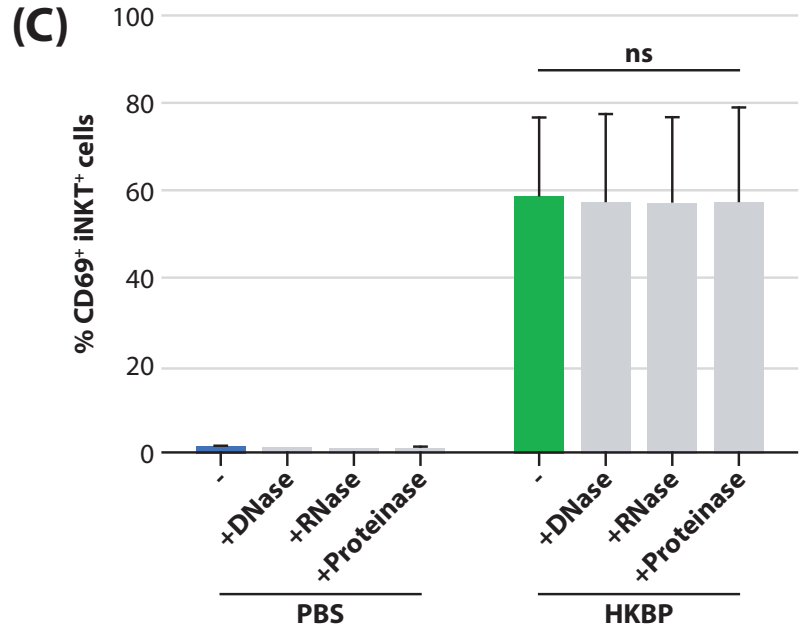

Figure 3. (Continued)

\section{Discussion}

The iNKT cells play an important role against several infectious diseases. ${ }^{21,22}$ We showed here for the first time that human iNKT cells are involved during melioidosis infection in human. The level of circulating iNKT cells in melioidosis patients was significantly lower than the healthy control. This finding is consistent with other reports such as autoimmune diseases, bacterial and viral infections..$^{23,24}$ In case of patients with tuberculosis, iNKT cells were decreased but had a stimulated phenotype. ${ }^{25,26}$ On the other hand, circulating iNKT cells have been found to be increased in primary Sjogren syndromes while iNKT cells number were not different in comparison between patients with scrub typhus and healthy controls. The decrease in circulating iNKT cells might be the consequence from the in vivo activation of iNKT cells via $\mathrm{T}$ cell receptor (TCR) recognition, of which leading to the TCR internalization that cannot be detected by tetramer/dimer staining methods. ${ }^{27,28}$ Another possibility is that B. pseudomallei might stimulate iNKT cells and induce apoptosis similar to what was found in Mycobacterium tuberculosis infection. ${ }^{28-30}$ The apoptosis of iNKT cells in patients with pulmonary tuberculosis were from the chronic activation of glycolipid MTB antigen. ${ }^{28}$ The decrease in iNKT cells may also come from $B$. pseudomallei stimulation that down-regulate the iNKT TCR rendering the lower number of iNKT cells as observed by flow cytometry during early stages of infection. Another possibility is the migration of iNKT cells out of the circulation to accumulate at the infection sites. ${ }^{28}$ As the number of circulating iNKT cells in the patients prior to B. pseudomallei infection was not known, it is also possible that the individuals might have low levels of iNKT cells before infection that render them to be more susceptible to the disease.

In this study, the iNKT cells were found to be activated in blood samples of patients with sepsis melioidosis as well as when cultured in vitro with heat-killed B. pseudomallei, suggesting that $B$. pseudomallei could stimulate the iNKT cells. Unfortunately, there was no significant correlation between patients who survived and activation of iNKT cells. This might be due to the limited number of patients investigated. A follow up study to measure iNKT cells in those patients who survived after onset of melioidosis would be useful
(D)

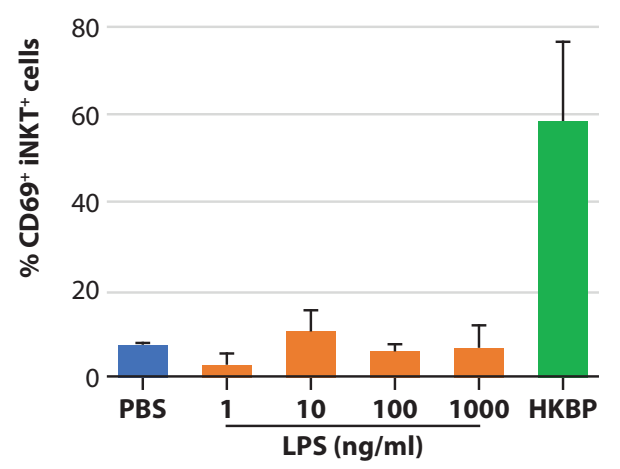

for determining whether iNKT cells play any important role during infection. In other infections, it was reported that iNKT cells were activated in response to diverse range of infectious agents, including gram-positive and gram-negative bacteria, and mycobacteria. ${ }^{12}$ The possible mechanisms by which iNKT cells were activated during infection can be separated into 2 major pathways including direct activation (microbial-antigen mediated) and indirect activation (endogenous-antigen mediated, cytokine mediated, or a combination). ${ }^{12}$ The activation of iNKT cells may influence other adaptive immune cells such as T and B cell responses. ${ }^{9}$

Several bacterial components could stimulate iNKT cells such as a-glucosyl diacylglycerol from Streptococcus pneumoniae, a-galactosyl diacylglycerol from Borrelia burgdorferi, and a-glucuronosyl from Sphingomonas. ${ }^{31}$ We also attempted to determine the B. pseudomallei crude components, which induces iNKT cell activation. Our data showed that DNA, RNA, and protein of $B$. pseudomallei were not associated with iNKT cell stimulation (Figure 3C). There have been reports demonstrated that lipopolysaccharide from gram-negative bacteria such as Salmonella Typhimurium and Escherichia coli can stimulate iNKT cells during bacterial infections. ${ }^{32}$ LPS from Salmonella Typhimurium can activate iNKT cells via interleukin 12 (IL-12) that produced from dendritic cells and CD1d recognition. ${ }^{33}$ In the case of Escherichia coli, LPS-induced IL12 and IL-18 from dendritic cells were sufficient to stimulate iNKT cells. ${ }^{34}$ Accordingly, we hypothesized that LPS from $B$. pseudomallei might be able to activate iNKT cells. Surprisingly iNKT cells could not be activated after stimulated with $B$. pseudomallei LPS (Figure 3D). This finding led us to hypothesize that other molecules such as lipid, or glycolipid from this bacterium might be the major activators for iNKT cells. In mouse model, $B$. pseudomallei could produce a bioactive sphingolipid metabolite during intracellular infection and it was found to associate with bacterial virulence. ${ }^{35}$ This lipid might be a possible molecule that could stimulate the iNKT cells. Alternatively, iNKT cells might be indirectly activated by cytokines mediated or endogenous lipid pathways. Further study is needed to identify the components of B. pseudomallei that induced iNKT cell stimulation. 
In summary, B. pseudomallei could stimulate iNKT cells and the molecules that involve in activation were not DNA, RNA, protein or LPS. These findings provide the first information about the role of human iNKT cells against $B$. pseudomallei infection. The lower number of iNKT cells in septic melioidosis patients obtained will be a beginning of iNKT cells study in melioidosis and lead to better understanding of its role in this bacterial infection.

\section{Acknowledgments}

This research was supported by the Thailand Research Fund and Khon Kaen University through the Royal Golden Jubilee Ph.D. Program (Grant number PHD/0040/2557), Faculty of Medicine, Khon Kaen University, Thailand (Grant number IN60118) and the Melioidosis Research Center, Faculty of Medicine, Khon Kaen University, Khon Kaen, Thailand.

\section{References}

1. Meumann EM, Cheng AC, Ward L, Currie BJ. Clinical features and epidemiology of melioidosis pneumonia: results from a 21-year study and review of the literature. Clin Infect Dis. 2012;54:362-9.

2. Hantrakun V, Kongyu S, Klaytong P, Rongsumlee S, Day NPJ, Peacock SJ, et al. Clinical Epidemiology of 7126 Melioidosis patients in Thailand and the implications for a national notifiable diseases surveillance system. Open Forum Infect Dis. 2019;6:ofz 498.

3. Chantratita N, Tandhavanant S, Myers ND, Seal S, Arayawichanont A, Kliangsa-Ad A, et al. Survey of innate immune responses to Burkholderia pseudomallei in human blood identifies a central role for lipopolysaccharide. PLoS One. 2013;8:e81617.

4. Lauw FN, Simpson AJ, Prins JM, Smith MD, Kurimoto M, van Deventer SJ, et al. Elevated plasma concentrations of interferon (IFN)- $\gamma$ and the IFN- $\gamma$-inducing cytokines interleukin (IL)-18, IL-12, and IL-15 in severe melioidosis. J Infect Dis. 1999;180:1878-85.

5. Kronsteiner B, Chaichana P, Sumonwiriya M, Jenjaroen K, Chowdhury FR, Chumseng S, et al. Diabetes alters immune response patterns to acute melioidosis in humans. Eur J Immunol. 2019;49:1092-106.

6. Ketheesan N, Barnes JL, Ulett GC, VanGessel HJ, Norton RE, Hirst RG, et al. Demonstration of a cell-mediated immune response in melioidosis. J Infect Dis. 2002;186:286-9.

7. Ren Y, Sekine-Kondo E, Shibata R, Kato-Itoh M, Umino A, Yanagida A, et al. A novel mouse model of iNKT cell-deficiency generated by CRISPR/ Cas9 reveals a pathogenic role of iNKT cells in metabolic disease. Sci Rep. 2017;7:12765.

8. Sartorius R, D’Apice L, Barba P, Cipria D, Grauso L, Cutignano A, et al. Vectorized delivery of alpha-galactosylceramide and tumor antigen on filamentous bacteriophage fd induces protective immunity by enhancing tumor-specific T cell response. Front Immunol. 2018;9:1496.

9. Brigl M, Tatituri RV, Watts GF, Bhowruth V, Leadbetter EA, Barton N, et al. Innate and cytokine-driven signals, rather than microbial antigens, dominate in natural killer $\mathrm{T}$ cell activation during microbial infections. J Exp Med. 2011;208:1163-77

10. Skold M, Behar SM. Role of CD1d-restricted NKT cells in microbial immunity. Infect Immun. 2003;71:5447-55.

11. Kohlgruber AC, Donado CA, LaMarche NM, Brenner MB, Brennan PJ Activation strategies for invariant natural killer $\mathrm{T}$ cells. Immunogenetics. 2016;68:649-63

12. Tupin E, Kinjo Y, Kronenberg M. The unique role of natural killer T cells in the response to microorganisms. Nat Rev Microbiol. 2007;5:405-17.

13. Reilly EC, Wands JR, Brossay L. Cytokine dependent and independent iNKT cell activation. Cytokine. 2010;51:227-31.
14. Sun GW, Lu J, Pervaiz S, Cao WP, Gan YH. Caspase-1 dependent macrophage death induced by Burkholderia pseudomallei. Cell Microbiol. 2005;7:1447-58.

15. Easton A, Haque A, Chu K, Lukaszewski R, Bancroft GJ. A critical role for neutrophils in resistance to experimental infection with Burkholderia pseudomallei. J Infect Dis. 2007;195:99-107.

16. Charoensup J, Sermswan RW, Paeyao A, Promakhejohn S, Punasee S, Chularari C, et al. High HMGB1 level is associated with poor outcome of septicemic melioidosis. Int J Infect Dis. 2014;28:111-6.

17. Watarai H, Nakagawa R, Omori-Miyake M, Dashtsoodol N, Taniguchi M. Methods for detection, isolation and culture of mouse and human invariant NKT cells. Nat Protoc. 2008;3:70-8.

18. Sengyee S, Yoon SH, Paksanont S, Yimthin T, Wuthiekanun V, Limmathurotsakul D, et al. Comprehensive analysis of clinical Burkholderia pseudomallei isolates demonstrates conservation of unique lipid A structure and TLR4-dependent innate immune activation. PLoS Negl Trop Dis. 2018;12:e0006287.

19. Kang SJ, Jin HM, Cho YN, Oh TH, Kim SE, Kim UJ, et al. Dysfunction of circulating natural killer $\mathrm{T}$ cells in patients with scrub typhus. J Infect Dis. 2018;218:1813-21.

20. Sengyee S, Yoon SH, West TE, Ernst RK, Chantratita N Lipopolysaccharides from different Burkholderia species with different lipid A structures induce toll-like receptor 4 activation and react with melioidosis patient sera. Infect Immun. 2019;87.

21. Kinjo Y, Kitano N, Kronenberg M. The role of invariant natural killer T cells in microbial immunity. J Infect Chemother. 2013;19:560-70.

22. Khan MA, Khan A. Role of NKT cells during viral infection and the development of NKT cell-based nanovaccines. Vaccines. 2021;9:949.

23. Hobbs JA, Cho S, Roberts TJ, Sriram V, Zhang J, Xu M, et al. Selective loss of natural killer $\mathrm{T}$ cells by apoptosis following infection with lymphocytic choriomeningitis virus. J Virol. 2001;75:10746-54.

24. Kojo S, Adachi Y, Keino H, Taniguchi M, Sumida T. Dysfunction of T cell receptor AV24AJ18+, BV11+ double-negative regulatory natural killer T cells in autoimmune diseases. Arthritis Rheum. 2001;44:1127-38.

25. Montoya CJ, Catano JC, Ramirez Z, Rugeles MT, Wilson SB, Landay AL. Invariant NKT cells from HIV-1 or Mycobacterium tuberculosis-infected patients express an activated phenotype. Clin Immunol. 2008;127:1-6.

26. Berzins SP, Smyth MJ, Baxter AG. Presumed guilty: natural killer T cell defects and human disease. Nat Rev Immunol. 2011;11:131-42.

27. Motsinger A, Haas DW, Stanic AK, Van Kaer L, Joyce S, Unutmaz D. CD1d-restricted human natural killer $\mathrm{T}$ cells are highly susceptible to human immunodeficiency virus 1 infection. J Exp Med. 2002;195:869-79.

28. Snyder-Cappione JE, Nixon DF, Loo CP, Chapman JM, Meiklejohn DA, Melo FF, et al. Individuals with pulmonary tuberculosis have lower levels of circulating CD1d-restricted NKT cells. J Infect Dis. 2007;195:1361-4.

29. Kee SJ, Kwon YS, Park YW, Cho YN, Lee SJ, Kim TJ, et al. Dysfunction of natural killer T cells in patients with active Mycobacterium tuberculosis infection. Infect Immun. 2012;80:2100-8.

30. Shekhar S, Joyee AG, Yang X. Invariant natural killer T cells: boon or bane in immunity to intracellular bacterial infections? J Innate Immun. 2014;6:575-84.

31. Zajonc DM, Girardi E. Recognition of Microbial Glycolipids by Natural Killer T Cells. Front Immunol. 2015;6:400.

32. Van Kaer L, Parekh VV, Wu L. The Response of CD1d-Restricted Invariant NKT Cells to Microbial Pathogens and Their Products. Front Immunol. 2015;6:226.

33. Brigl M, Bry L, Kent SC, Gumperz JE, Brenner MB. Mechanism of CD1d-restricted natural killer $\mathrm{T}$ cell activation during microbial infection. Nat Immunol. 2003;4:1230-7.

34. Nagarajan NA, Kronenberg M. Invariant NKT cells amplify the innate immune response to lipopolysaccharide. J Immunol. 2007;178:2706-13.

35. Custodio R, McLean CJ, Scott AE, Lowther J, Kennedy A, Clarke DJ, et al. Characterization of secreted sphingosine-1-phosphate lyases required for virulence and intracellular survival of Burkholderia pseudomallei. Mol Microbiol. 2016;102:1004-19. 


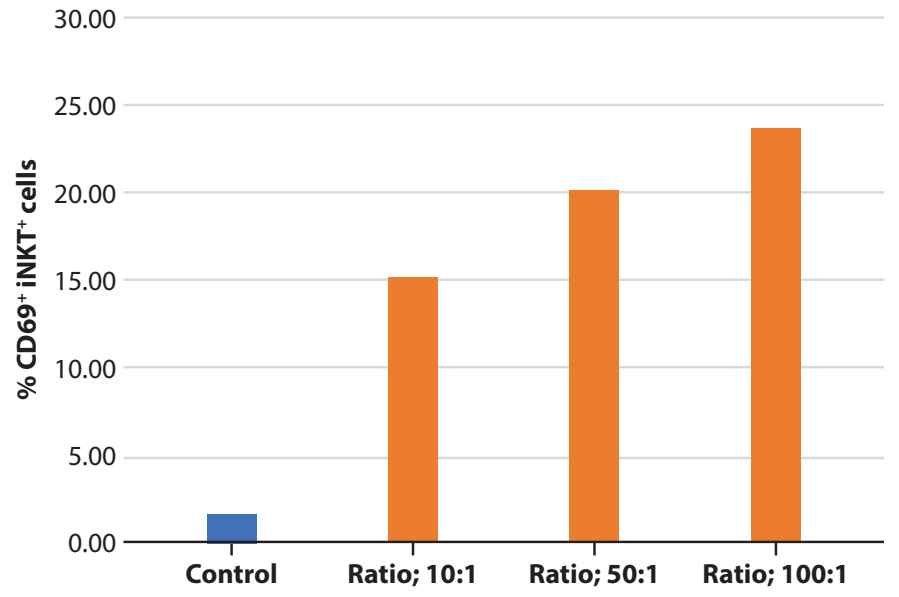

Supplement Figure 1. The activation of human iNKT cells by heat-killed $\boldsymbol{B}$. pseudomallei. PBMC from healthy persons were incubated with heat-killed B. pseudomallei at various ratios of heat-killed bacteria: PBMC 10:1, 50:1, and 100:1). After incubation, cells were stained with antibodies and analyzed by flow cytometry for determine iNKT cells. Each bar represented percentage of CD69 of iNKT cells after stimulated with heat-killed B. pseudomallei (orange bars) and an unstimulated control (blue bar). 